\title{
Mating Type and Simple Sequence Repeat Markers Indicate a Clonal Population of Phyllosticta citricarpa in Florida
}

\author{
Nan-Yi Wang, Ke Zhang, Jose C. Huguet-Tapia, Jeffrey A. Rollins, and Megan M. Dewdney
}

All authors: Department of Plant Pathology, University of Florida, Gainesville, and first, second, and fifth authors: Citrus Research and Education Center, University of Florida, Lake Alfred. Accepted for publication 29 May 2016.

\begin{abstract}
Wang, N.-Y., Zhang, K., Huguet-Tapia, J. C., Rollins, J. A., and Dewdney, M. M. 2015. Mating type and simple sequence repeat markers indicate a clonal population of Phyllosticta citricarpa in Florida. Phytopathology 106:1300-1310.

Phyllosticta citricarpa, the citrus black spot pathogen, was first identified in Florida in March 2010. Subsequently, this pathogen has become established in Florida but can be easily confused with the endemic nonpathogenic citrus endophyte $P$. capitalensis. In this study, the mating-type (MAT) loci of P. citricarpa and P. capitalensis were identified via draft genome sequencing and were characterized at the structural and sequence levels. P. citricarpa was determined to have an

idiomorphic, heterothallic MAT locus structure, whereas $P$. capitalensis was found to have a single $M A T$ locus consistent with a homothallic mating system. A survey of $P$. citricarpa isolates from Florida revealed that only the MAT1-2 idiomorph existed in the Floridian population. In contrast, isolates collected from Australia exhibited a 1:1 ratio of MAT1-1 and MAT1-2 isolates. Development and analysis of simple sequence repeat markers revealed a single multilocus genotype (MLG) in the Floridian population $(n=70)$ and 11 MLG within the Australian population $(n=24)$. These results indicate that isolates of $P$. citricarpa from Florida are likely descendent from a single clonal lineage and are reproducing asexually. The disease management focus in Florida will need to be concentrated on the production and dispersal of pycnidiospores.
\end{abstract}

Citrus black spot caused by Phyllosticta citricarpa (McAlpine) van der Aa (teleomorph: Guignardia citricarpa Kiely) has been reported from many citrus-growing areas with humid subtropical climates, including regions in Southeast Asia, Oceania, Africa, South America, and most recently, North America (Kotzé 1981; Paul et al. 2005; Schubert et al. 2012; Yonow et al. 2013). The disease affects all commercially grown citrus cultivars, including sweet orange, mandarin, grapefruit, and lemon, among which lemon is the most susceptible (Baldassari et al. 2008; Kotzé 1981). Although sour orange (C. aurantium) and Tahiti lime (C. latifolia) do not produce citrus black spot symptoms, $P$. citricarpa can none-the-less be isolated from asymptomatic host tissue (Baldassari et al. 2008; Kotzé 1981). Citrus black spot can cause multiple, rind-limited fruit symptoms including hard spot, false melanose, freckle spot, cracked spot, and virulent spot (de Goes et al. 2000; Kiely 1948, 1949; Kotzé 1981). While blemished fruit is unappealing and unsuitable in the fresh market, the internal juice quality is not affected (Kotzé 1981). However, when citrus groves are severely infected by citrus black spot, fruit yield declines due to premature fruit drop (Kiely 1949; Kotzé 1981; Spósito et al. 2011), which is a particular concern for juice processors. Furthermore, P. citricarpa is currently listed as an A1 quarantine pest by the European and Mediterranean Plant Protection Organization. The European Union (EU) quarantine measures for citrus black spot have considerably slowed or prevented citrus export to the EU from countries with the disease (European Food Safety Authority (EFSA) 2014).

While citrus black spot inoculum can consist of either ascospores or pycnidiospores (conidia originating from pycnidia), epidemiological

Corresponding authors: J. A. Rollins; E-mail address: rollinsj@ufl.edu and M. M. Dewdney; E-mail address: mmdewdney@ufl.edu

*The $e$-Xtra logo stands for "electronic extra" and indicates that three supplementary tables are published online.

http://dx.doi.org/10.1094/PHYTO-12-15-0316-R

(C) 2016 The American Phytopathological Society studies outside of North America indicate the most important inoculum for the spread of citrus black spot is ascospores, which are solely produced in decomposing leaf litter under alternating wetting and drying cycles (Kotzé 1981; Reis et al. 2006; Spósito et al. 2008). During leaf-wetting events, ascospores are forcibly ejected up to $1.2 \mathrm{~cm}$ from mature pseudothecia and carried over some distance $(<24.7 \mathrm{~m}$ ) by wind currents to susceptible plant tissue (Spósito et al. 2007). Conidia produced by pycnidia on symptomatic fruit, dead twigs, or decomposing leaves are considered a source of secondary inoculum. This secondary inoculum plays an important role in spread within plant canopies in areas such as Brazil and, presumably, Florida, where an overlap of fruit maturities and frequent summer rains occur (Spósito et al. 2011). However, in South Africa and Australia, conidia are less important to the disease epidemiology, because the seasonal rainfall is limited in the summer, the bloom is restricted by cooler weather and irrigation practices, and fruit is usually harvested from trees before new fruit set begins (Kotzé 1981; Spósito et al. 2008).

Despite the well-documented role of ascospores in the epidemiology of citrus black spot (Kotzé 1981; McOnie 1964; Reis et al. 2006; Spósito et al. 2008), the factors regulating $P$. citricarpa ascospore production are unclear. Sexual reproduction in the Ascomycota is controlled by a single MAT locus with two idiomorphs, known as MAT1-1 and MAT1-2 (Debuchy and Turgeon 2006; Lee et al. 2010; $\mathrm{Ni}$ et al. 2011). The MAT1-1 idiomorph contains the MAT1-1-1 gene encoding an $\alpha$-box protein, and the MAT1-2 idiomorph carries the MAT1-2-1 gene encoding a high mobility group (HMG)-domain protein (Lee et al. 2010; Ni et al. 2011). In heterothallic species, sexual reproduction occurs when opposite mating type partners interact (Lee et al. 2010; Ni et al. 2011). In contrast, homothallic fungi contain both MAT1-1-1 and MAT1-2-1 genes either in a fused MAT locus or in proximity, which allows the initiation of sexual reproduction without the requirement for an isolate of opposite mating type (Lee et al. 2010; Ni et al. 2011). Although this is the most commonly observed scenario, exceptions to this general $M A T$ locus structure and regulation of mating have been reported 
(Butler et al. 2009; O'Connell et al. 2012; Vaillancourt et al. 2000). Because $P$. citricarpa is not fertile in single spore-derived cultures, this species is presumed heterothallic but the MAT locus structure and underlying regulation has not been characterized.

Given that $P$. citricarpa is an emerging pathogen in Florida, establishing the genetic structure of its one or more populations and determining whether the populations are undergoing random mating can provide valuable information for epidemiological modeling and disease management. A previous study evaluated the genetic diversity of $P$. citricarpa isolates from Florida, using multilocus sequence analysis with four conserved loci (ITS, TEF1, ACT, and GPDH) and a small number of $P$. citricarpa isolates from Florida, Brazil, South Africa, Zimbabwe, and Australia (Zavala et al. 2014). This study found that isolates, regardless of origin, were genotypically indistinguishable. This finding is likely attributed to the conserved nature of the four chosen markers. Greater genotypic resolution using markers such as simple sequence repeat (SSR) loci are needed to determine the genetic structure of $P$. citricarpa populations in Florida and compare this to populations from other citrus production areas.

In addition to $P$. citricarpa, $P$. capitalensis is commonly isolated from both diseased and healthy citrus fruit (Baayen et al. 2002; Glienke et al. 2011). P. capitalensis is a ubiquitous endophyte asymptomatically colonizing citrus and many other hosts (Glienke et al. 2011). These two Phyllosticta species are morphologically very similar, but a single culture of $P$. capitalensis can produce fertile pseudothecia on artificial media (Baayen et al. 2002; Baldassari et al. 2008) whereas $P$. citricarpa cannot (Baayen et al. 2002; Baldassari et al. 2008; McOnie 1964). From these observations, $P$. capitalensis has been presumed to have a homothallic mating system and P. citricarpa a heterothallic system. A single report (Moran Lemir et al. 2000) concerning P. citricarpa ascospore production from a single isolate on an artificial medium has not been repeated by other groups (Baldassari et al. 2008), including our own. Whether the conditions for ascospore production by $P$. citricarpa have not been appropriate or whether $P$. citricarpa requires an opposite $M A T$ type isolate to achieve sexual reproduction remains unknown. The overall objectives of this study were to identify and characterize MAT loci of P. citricarpa and $P$. capitalensis and to assess the genetic structure of the Floridian population of $P$. citricarpa. We utilized genomic sequence data and SSR markers generated in this study to test the hypothesis that $P$. citricarpa has a heterothallic mating structure and is randomly mating in Florida. The knowledge gained in this study will greatly improve our understanding of the epidemiology of citrus black spot in Florida and facilitate the development of disease control strategies aimed at limiting the spread of the disease.

\section{MATERIALS AND METHODS}

Fungal isolation and maintenance. The $113 P$. citricarpa isolates and one $P$. capitalensis isolate from Florida and DNA samples of 26 P citricarpa isolates from Australia, provided by A. Miles (Miles et al. 2013), used in this study were isolated from freckle spot lesions, hard spot lesions, or pycnidia within lesions on symptomatic citrus fruit (Supplementary Table S1). The identity of all fungal isolates was verified based on the production of yellow pigment on oatmeal agar (Baayen et al. 2002) and using speciesspecific primers designed by Peres et al. (2007). Afterward, fungal isolates were single-spored, were kept on colonized sterile filter paper in sterile coin envelopes, and were stored in plastic containers with desiccants in $\mathrm{a}-20^{\circ} \mathrm{C}$ freezer, as described by Hincapie et al. (2014). When needed, small pieces of filter paper were transferred onto half-strength potato dextrose agar ( $1 / 2 \mathrm{PDA}$ ) (Difco, BD, Sparks, MD) and were maintained at $24^{\circ} \mathrm{C}$ under a 12 -h photoperiod until use.

DNA isolation and genome sequencing. To isolate genomic DNA (gDNA), the method described by $\mathrm{Hu}$ et al. (2014) was adopted. Briefly, fungal mycelia were grown on $1 / 2$ PDA with a layer of cellophane at $24^{\circ} \mathrm{C}$ under a 12 -h photoperiod for 6 days. Following this growth period, $100 \mathrm{mg}$ of fungal mycelia was scraped from the cellophane, was transferred into 2.0 -ml screw cap tubes with sterile 5 -mm stainless steel beads, was flash frozen with liquid nitrogen, and was homogenized twice for $30 \mathrm{~s}$ at $30 \mathrm{~Hz}$, using a Qiagen TissueLyser II (Qiagen, Valencia, CA). gDNA was then isolated using the Qiagen plant mini kit (Qiagen), based on the manufacturer's protocol. The quality and quantity of gDNA was determined by measuring the absorbance at 260 to $280 \mathrm{~nm}$ and 260 to $230 \mathrm{~nm}$, using a NanoDrop ND-1000 spectrophotometer (Thermo Fisher Scientific, Waltham, MA). All DNA samples were stored at $-20^{\circ} \mathrm{C}$ until use.

To obtain gDNA for genome sequencing, gDNA samples from arbitrarily selected Floridian P. citricarpa isolate Gc12 and Floridian $P$. capitalensis isolate Gm33 were further purified by phenol-chloroform extraction and ethanol precipitation. The quality and quantity of gDNA was determined as above and by electrophoresis on a $0.6 \%$ agarose gel. More than $5 \mu \mathrm{g}$ of gDNA, each, of $P$. citricarpa Gc12 and P. capitalensis Gm33 were submitted to the Interdisciplinary Center for Biotechnology Research (ICBR) Genomics Core at the University of Florida. Single-end sequencing was performed twice independently for each species on the Ion Torrent Personal Genome Machine (PGM) platform using 200- or 400-bp chemistry on an Ion 318 chip (Life Technologies, Carlsbad, CA).

Identification of $\boldsymbol{M A T}$ loci. Raw sequencing data from Ion Torrent PGM were de novo assembled using the de Bruijn algorithm implemented in the CLC Genomics Workbench version 5.0.1 (CLC Bio, Aarhus, Denmark) and the SPAdes genome assembler (version 3.5) (Bankevich et al. 2012). Multiple criteria including N50 value, total contig number, and the average contig length were used to decide the best assembly. Final assembly parameters utilized a window size of 20 and 30 nucleotides, a bubble of 175 and 400 nucleotides, and a minimum contig length of 200 nucleotides for sequencing data of $P$. citricarpa Gc12 and P. capitalensis Gm33, respectively. Protein-encoding genes were predicted from the assembly using the $a b$ initio algorithm GeneMark-ES (TerHovhannisyan et al. 2008). Homology searches were performed using BLASTn and BLASTp algorithms against the National Center for Biotechnology Information (NCBI) database and were displayed using EPoS 0.9.1 (Griebel et al. 2008) to search for MATassociated genes, including MAT1-1-1, MAT1-2-1, apn2 (DNA lyase), and sla2 (cytoskeleton assembly control protein) genes.

During the analysis of genomic data from P. citricarpa $\mathrm{Gc12}$, a $P$. citricarpa isolate from China, CGMCC3.14348, became available in the NCBI database (accession number AOTE00000000). This Chinese $P$. citricarpa genome was annotated and analyzed as above to identify and comparatively analyze its $M A T$ locus relative to the MAT locus from Gc12.

Amplification of the flanking region and the coding sequence of MAT1-2-1 of $P$. citricarpa. To determine the flanking sequence of MAT1-2-1 of P. citricarpa, conventional polymerase chain reaction (PCR) using GcMAT-HMG-7 and GcMAT-PH-4 primers (Table 1) was performed in a $25-\mu 1$ reaction volume containing 1 to $10 \mathrm{ng}$ of gDNA, $0.2 \mu \mathrm{M}$ of each primer, $0.2 \mathrm{mM}$ of each dNTP, $1 \times$ PCR reaction buffer, and $1 \mathrm{U}$ of HotStar Taq polymerase (Qiagen), using an MJ Research PTC-200 Peltier thermal cycler (Bio-Rad Laboratories, Hercules, CA), according to the following conditions: $95^{\circ} \mathrm{C}$ for $5 \mathrm{~min}, 40$ cycles of $94^{\circ} \mathrm{C}$ for $30 \mathrm{~s}, 56^{\circ} \mathrm{C}$ for $30 \mathrm{~s}$, and $72^{\circ} \mathrm{C}$ for $1 \mathrm{~min}$, followed by a final extension of $5 \mathrm{~min}$ at $72^{\circ} \mathrm{C}$. PCR amplicons were cloned into the pGEM-T Easy vectors (Promega Crop., Madison, WI) and were sequenced by Sanger chemistry at the ICBR, followed by BLASTn analysis against the NCBI database.

To determine the coding sequence of MAT1-2-1 of $P$. citricarpa, total RNA was extracted using the Qiagen RNeasy plant mini kit (Qiagen), following the instructions of the manufacturer, was 
quantified using a NanoDrop ND-1000, and was reverse transcribed into complementary DNA using SuperScript III reverse transcription (Invitrogen, Grand Island, NY) and oligo-dT 20 , based on the instructions of the manufacturer. PCR reactions using GcitMATHMG-1 (5'-TTTCCTCTACTCAAGACCCTTCCC- $3^{\prime}$ ) and oligo$\mathrm{dT}_{20}$ were performed according to the conditions above, except the annealing temperature was $50^{\circ} \mathrm{C}$. Subsequently, a nested PCR was performed as above, using primer GcitMAT-HMG-3 (5'-GCTCT CCACACGTTCCAGTCCC- $3^{\prime}$ ) and oligo-dT 20 with 100-fold diluted PCR products, and the resulting amplicons were cloned and sequenced as above.

Sequence alignment and phylogenetic analysis. Dot plot analysis of MAT1-1 and MAT1-2 of P. citricarpa was performed using the nucleic acid dot plot program on the Molecular Toolkit website (Maizel and Lenk 1981). Synteny analysis between MAT1-1 and MAT1-2 of P. citricarpa and between MAT idiomorphs of $P$. citricarpa and $P$. capitalensis was performed using the Artemis comparison tool (Carver et al. 2005). Sequence identity was analyzed using the Needleman-Wunsch global alignment algorithm available on the NCBI website. Predicted amino acid sequences of the PH-domain proteins of $P$. citricarpa and $P$. capitalensis were aligned using ClustalW2 along with other PH-domain proteins of Dothideomycetes, obtained from GenBank and the Joint Genome Institute genome databases (Supplementary Table S2). The maximum likelihood phylogenetic tree of amino acid sequences was generated accordingly, using MEGA version 6.0.5 (Tamura et al. 2013) with 1,000 bootstrap replicates under the Le and Gascuel (LG) + Gamma (G) model.

Screening of $\boldsymbol{M A T}$ idiomorphs of $\boldsymbol{P}$. citricarpa. To determine the mating type of Floridian $P$. citricarpa isolates, specific primers targeting the coding sequence of MAT1-1-1 or MAT1-2-1 (Table 1) were designed, using Primer Premier version 5.0 (Premier Biosoft International, Palo Alto, CA) with the default settings. To validate the primer specificity, PCR reactions were performed under the following cycling conditions: $95^{\circ} \mathrm{C}$ for $5 \mathrm{~min}, 40$ cycles of $95^{\circ} \mathrm{C}$ for $30 \mathrm{~s}, 55^{\circ} \mathrm{C}$ or $60^{\circ} \mathrm{C}$ for $45 \mathrm{~s}$, and $72^{\circ} \mathrm{C}$ for $45 \mathrm{~s}$, with a final extension of $10 \mathrm{~min}$ at $72^{\circ} \mathrm{C}$. The resulting PCR products were analyzed by electrophoresis on a $1 \%$ agarose gel with SYBR Safe DNA stain (Invitrogen) in $1 \times$ Tris-acetate-EDTA (40 mM Tris, $20 \mathrm{mM}$ acetic acid, $1 \mathrm{mM}$ EDTA, $\mathrm{pH} 8.4$ ) buffer at $110 \mathrm{~V}$ for $30 \mathrm{~min}$ and were visualized under ultraviolet light using a UVP-MultiDoc-It digital imaging system (UVP, Upland, CA). gDNA of $P$. citricarpa isolates BRIP 27888 from Australia and Gc12 from Florida were used as positive controls for MAT1-1 and MAT1-2 idiomorphs, respectively. gDNA from $P$. capitalensis isolate Gm33 was used as a negative control. Nuclease-free water (Qiagen) was used as a nontemplate control. The 113 Floridian isolates collected from 2010 through 2013 and 26 gDNA samples from the Australian population were evaluated for mating type loci using primers. $\chi^{2}$ tests using PROC FREQ in SAS version 9.4 (SAS Institute, Cary, NC) were performed at $P=0.05$, to compare the MAT1-1:MAT1-2 ratio in each population to a $1: 1$ ratio.

SSR marker screening and primer design. Genome sequences of the Floridian isolate Gc12 and the Chinese isolate CGMCC3.14348 were analyzed with the default settings of the online tool BatchPrimer3 (You et al. 2008) to identify potential SSR markers and corresponding primer pairs. Afterward, primer pairs were manually compared with select polymorphic SSR markers between the genomes of the two isolates. In total, 13 primer pairs were selected for further PCR assays. A summary of SSR markers and primers is shown in Table 2. To adopt a method for economically labeling PCR fragments with a fluorescent dye (Schuelke 2000), an M13 tail (5'-TGTAAAACG ACGGCCAGT- $3^{\prime}$ ) was linked to the $5^{\prime}$ end of the forward primer of each primer pair, and the universal M13 primer (5'-TGTAAAACG ACGGCCAGT-3') labeled with 6-FAM was then used for incorporation of the fluorescent dye into PCR products. To fit the 96-well format of downstream processes, gDNA of the 72 Floridian $P$. citricarpa isolates, representative of the geographical and temporal diversity of all isolates, and 26 arbitrarily selected Australian isolates were chosen for genotyping analysis. DNA was exhausted in preliminary trials from two of the original 26 Australian isolates and DNA from two of the 72 gDNAs from the Floridian isolates failed to amplify. These isolates were eliminated from further analysis such that, in total, 70 Floridian isolates and 24 Australian isolates were analyzed. Touchdown PCR was performed in $15-\mu \mathrm{l}$ reaction volumes $(0.5 \mu \mathrm{l}$ of gDNA [5 to $10 \mathrm{ng}$ ], $0.05 \mu \mathrm{M}$ of M13-tailed forward primer, $0.2 \mu \mathrm{M}$ of reverse primer, $0.2 \mu \mathrm{M}$ of 6-FAM-labeled M13 universal primer, $0.2 \mathrm{mM}$ of each dNTP, $1 \times$ PCR reaction buffer, $2 \mathrm{mM}$ of $\mathrm{MgCl}_{2}$, and $0.025 \mathrm{U}$ of Taq DNA polymerase per microliter [Qiagen]), under the following cycling conditions: $95^{\circ} \mathrm{C}$ for $5 \mathrm{~min}, 20$ cycles of $95^{\circ} \mathrm{C}$ for $30 \mathrm{~s}$, $60^{\circ} \mathrm{C}$ for $30 \mathrm{~s}$, with a decrease of annealing temperature of $0.5^{\circ} \mathrm{C}$ in each cycle, and $72^{\circ} \mathrm{C}$ for $30 \mathrm{~s}$, followed by 25 cycles of $95^{\circ} \mathrm{C}$ for $30 \mathrm{~s}, 50^{\circ} \mathrm{C}$ for $45 \mathrm{~s}$, and $72^{\circ} \mathrm{C}$ for $45 \mathrm{~s}$, with a final extension of $45 \mathrm{~min}$ at $72^{\circ} \mathrm{C}$.

Fragment length analysis and population genetic statistics. Fragment analysis of PCR products was performed on an Applied BioSystems 3730xl DNA Analyzer at the ICBR with the GeneScan 600 LIZ size standard (Applied Biosystems by Life Technologies). Allele size was determined using GeneMarker Software version 2.6.3 (SoftGenetics, State college, PA) and analyzed using GenAlEx version 6.5 (Peakall and Smouse 2012). Population genetic statistics including Nei's unbiased genotypic diversity (Hexp), Simpson's index of diversity (1-D), evenness (E.5), number of multilocus genotypes (MLG), number of expected MLG at the smallest sample size (eMLG), Shannon-Wiener index of MLG diversity (H), Stoddart and Taylor's index of MLG diversity (G), index of association $\left(I_{A}\right)$, and standardized index of association $\left(\bar{r}_{d}\right)$ were determined with the poppr package in $\mathrm{R}$ (version 2.0.2) (Kamvar et al. 2014). Hexp is the probability of two randomly chosen genotypes being different and ranges from zero to one. $1-\mathrm{D}$ is also the probability that two randomly selected individuals belong to different genotypes. E.5 is the distribution of genotype abundances and ranges from zero, where a single genotype is dominant within a population, to one, where genotypes are equally abundant within a population. Under the random mating scenario, eMLG would be equal to MLG, and a larger H or G would be revealed due to the high genetic diversity of a population. For $I_{A}$ and $\bar{r}_{d}$, the null hypothesis was that the loci are independently associated and the population is expected to undergo random mating. If the observed $I_{A}$ and $\bar{r}_{d}$ were not significantly different from those obtained from the randomized

TABLE 1. Primers used for amplification of the mating-type (MAT) locus of Phyllosticta citricarpa

\begin{tabular}{llccc}
\hline Name & \multicolumn{1}{c}{ Primer sequence $\left(5^{\prime} \text { to } 3^{\prime}\right)^{\mathrm{a}}$} & $\mathrm{Tm}^{\mathrm{b}}\left({ }^{\circ} \mathrm{C}\right)$ & Amplicon size (bp) & Target \\
\hline Gcmat1-56f & CTCAAGCCCAAATCAATCAG & 60 & 630 & MAT1-1-1 \\
Gcmat1-686r & AGGATGTCAATGTGAGGGCA & 60 & 630 & MAT1-1-1 \\
Gcmat2-686f & CTTCAGCCAGCTTCTTCTTG & 55 & 500 & $M A T 1-2-1$ \\
Gcmat2-1185r & AGAGCAGAAGGTCTTGCGTA & 55 & 500 & $M A T 1-2-1$ \\
GcMAT-HMG-7 & CATCCGCCCACACATCAAAGCGACCTA & 56 & 448 & Intergenic region \\
GcMAT-PH-4 & CGGTGCTCTCCTTTTCACTGGA & 56 & 448 & Intergenic region \\
\hline
\end{tabular}

${ }^{a}$ Primers specifically targeting either MAT1-1-1 or MAT1-2-1 of P. citricarpa were designed using Primer Premier software version 5.0.

b $\mathrm{Tm}=$ melting temperature. 
data, the null hypothesis would not be rejected, indicating the population is consistent with random mating.

\section{RESULTS}

Identification of MAT loci. Initial attempts to isolate sequences of the $P$. citricarpa MAT locus followed a PCR-based strategy, using degenerate primers designed from MAT genes from Cochliobolus heterostrophus, Alternaria alternata, and Stagonospora nodorum (Arie et al. 1997, 2000; Bennett et al. 1999). None of the chosen primer combinations amplified a specific MAT locus sequence from $P$. citricarpa (data not shown). Subsequently, a draft genomesequencing strategy was pursued for $P$. citricarpa Gc12 and $P$. capitalensis $\mathrm{Gm} 33$, using two runs of semiconductor-based next generation sequencing technology for each species. For $P$. citricarpa (Gc12), $1.0 \times 10^{7}$ reads totaling 2,360 Mbp (1,889 Mbp of Q20 nucleotides) with a mean read length of $226 \mathrm{bp}$ were obtained. For P. capitalensis $(\mathrm{Gm} 33), 9.3 \times 10^{6}$ reads totaling 2,281 Mbp (1,745 Mbp of Q20 nucleotides) with a mean read length of $245 \mathrm{bp}$ were obtained. This whole-genome shotgun project has been deposited in the DDBJ/ENA/GenBank database under accession LOEN00000000 for Phyllosticta citricarpa Gc12 and under accession LOEO00000000 for Phyllosticta capitalensis Gm33. The versions described in this paper are versions LOEN01000000 and LOEO01000000, respectively.

From the assembled genome and predicted proteins of $P$. citricarpa isolate Gc12, BLAST queries using C. heterostrophus MAT1-2-1 identified a 1,463-bp fragment on contig 3787 (contig length = $16,464 \mathrm{bp})$ with an E-value of 9e-19. This fragment encoded a protein with high similarity to MAT1-2-1 from Sphaeropsis sapinea $(\mathrm{E}-\mathrm{value}=5 \mathrm{e}-31)$. Contig 3787 also contained a putatively conserved flanking gene of the MAT locus, apn2. Sequences of genes, including sla2, which have been reported to flank MAT loci of other ascomycete fungi were not predicted on this contig. Using BLASTn and BLASTp searches with $C$. heterostrophus MAT1-1-1 gene and protein as query sequences, no gene with homology to MAT1-1-1 was identified in the P. citricarpa Gc12 genome. Contig 513 (contig length $=29,282$ bp) in the assembled genome of $P$. capitalensis isolate Gm33 was identified by BLAST queries to encode proteins homologous to MAT1-1-1 from Neofusicoccum parvum with an E-value of 8e-47 and MAT1-2-1 of Diplodia seriata with an E-value of 8e-30. Similar to P. citricarpa, apn2 was the only conserved flanking gene identified in this contig. Following BLAST queries of the $P$. citricarpa isolate CGMCC 3.14348 genome using $C$. heterostrophus MAT genes as above, a gene of $1,941 \mathrm{bp}$ on contig 4071 (9,524 bp) was identified with an E-value of 3e-29. This gene was further verified to encode a homolog of MAT1-1-1 from $N$. parvum $(\mathrm{E}$-value $=5 \mathrm{e}-51)$, based on the subsequent BLASTp search of NCBI. No sequences sharing homology with MAT1-2-1 sequences were identified on contig 4071 or elsewhere in the P. citricarpa CGMCC3.14348 genome.

The structural organization of the $P$. citricarpa Gc12 MAT1-2 locus was predicted by comparative sequence analysis with P. capitalensis Gm33 contig 338. Subsequently, P. citricarpa PCR primers GcMAT-HMG-7 and GcMAT-PH-4 were designed and used to amplify sequences that joined contigs 3787 and 2477 to provide a complete MAT1-2 locus sequence. The AUGUSTUS gene prediction tool was used to generate gene models for this joined contig, as well as for contig 513 from Gm33 and contig 4071 from P. citricarpa CGMCC3.14348. Multiple sequence alignments with related sequences from GenBank were used to confirm the coding sequence predictions. Reverse transcription-PCR was used to confirm the coding sequence of P. citricarpa MAT1-2-1. The

TABLE 2. Simple sequence repeat markers and primers developed for Phyllosticta citricarpa

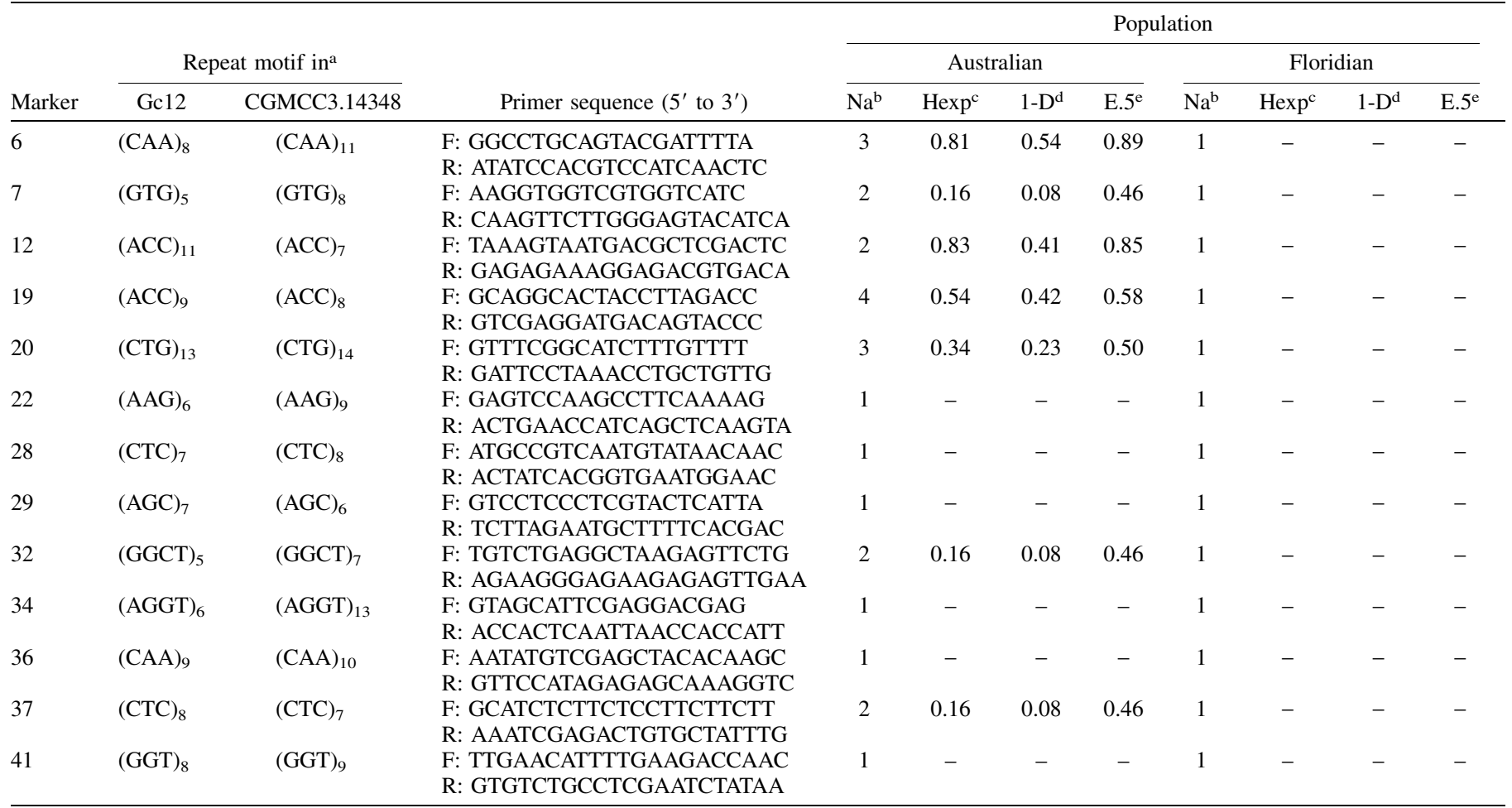

${ }^{a}$ Gc12 = P. citricarpa isolate with the MAT1-2 idiomorph; CGMCC3.14348 = P. citricarpa isolate with the MAT1-1 idiomorph.

${ }^{\mathrm{b}} \mathrm{Na}=$ allele number.

${ }^{c}$ Hexp = Nei's unbiased genotypic diversity, the probability of two randomly chosen genotypes being different, ranging from zero to one; the greater the value, the greater the diversity.

d 1-D = Simpson's index of diversity, the probability that two randomly selected individuals belong to different genotypes, ranging from zero to one; the greater the value, the greater the diversity.

${ }^{\mathrm{e}}$ E.5 = evenness, the distribution of genotype abundances, ranging from zero, where a single genotype is dominant within a population, to one, where genotypes are equally abundant within a population. 
resulting structural prediction of the $P$. citricarpa $\mathrm{Gc} 12$ and P. capitalensis Gm33 MAT loci are shown in Figure 1 and sequences were deposited in GenBank (accession numbers KT708823 and KT708824, respectively).

Defining boundaries of the $M A T$ loci. Synteny mapping between the $P$. citricarpa MAT idiomorphs determined the sequence boundaries of the MAT1-1 and MAT1-2 idiomorphs. The conserved flanking sequences of the MAT locus begin upstream at the start of the omll (overlapping MAT locus 1) 5' coding sequence and end downstream in the intergenic region of the 40S S9 gene (Figs. 1 and $2 \mathrm{~A}$ and B). While the BLASTp search revealed that OML1 of $P$. citricarpa is homologous to MAT1-1-4 of Diplodia pinea (E-value $=2 \mathrm{e}-06)$, the omll gene is primarily located in the conserved flanking sequences of both MAT idiomorphs of $P$. citricarpa and, therefore, as a whole is not considered part of the MAT locus (Figs. 1 and $2 \mathrm{~A}$ and B). From this analysis, the sequences that comprise the MAT1-1 and MAT1-2 idiomorphs are 6,005 and $6,623 \mathrm{bp}$, respectively.

Structurally, the MAT1-1 idiomorph contained one additional predicted gene downstream of MAT1-1-1; this gene encodes a protein with a putative integral membrane domain (the pleckstrin homology [PH] domain) (Fig. 1). The MAT1-2 idiomorph also encoded a $\mathrm{PH}$-domain protein downstream of the conserved MAT1-2-1 gene, but it appears to be only distantly related to the PH-domain gene of the MAT1-1 idiomorph, as the two sequences share only $56 \%$ identity at the nucleotide level. The MAT1-2 idiomorph also encoded a unique hypothetical protein located downstream of MAT1-2-1 and upstream of the PH-domain gene (Fig. 1). A BLASTp search of the NCBI database revealed that this hypothetical protein shared low identity to MAT1-2-5 of $D$. pinea $($ E-value $=1.9)($ Bihon et al. 2014). However, since the designation of MAT1-2-5 has been assigned to the cytochrome $c$ oxidase subunit VIa gene (cox13) in Coccidioides species (Mandel et al. 2007), MAT1-2-9 was, instead, used to designate this gene in the MAT1-2 idiomorph according to the nomenclature proposed by Turgeon and Yoder (2000).

Gene prediction and BLAST analysis of the P. capitalensis contig 338 revealed that the MAT locus of $P$. capitalensis contained both MAT1-1-1 and MAT1-2-1 genes in close proximity (Fig. 1). This locus also contained the MAT1-2-9 gene, a PH domain-encoding gene, and the conserved flanking genes found associated with the $P$. citricarpa MAT idiomorphs (Fig. 1). Synteny mapping between the MAT idiomorphs of $P$. citricarpa and the MAT locus of
$P$ c capitalensis revealed a conservation of gene composition between the species with a fused MAT1-1 and MAT1-2 idiomorph structure in $P$. capitalensis (Fig. 2). Pairwise comparison between the MAT1-1-1 and MAT1-2-1 genes of P. citricarpa with the $P$. capitalensis orthologs revealed 68 to $70 \%$ nucleotide sequence identity (59 to $65 \%$ amino acid identity) (Table 3 ). The omll gene of $P$. capitalensis shared similar nucleotide sequence identity (55 to $57 \%$ ) with the allelic copies of the $P$. citricarpa orthologs, which were $92 \%$ identical to each other (Table 3). The PH-domain gene from $P$. capitalensis shared greater nucleotide identity (72\%) with the $P$. citricarpa MAT1-2 PH-domain gene than with the $P$. citricarpa MAT1-1 PH-domain gene (54\%) (Table 3). Maximum-likelihood phylogenetic analysis using $\mathrm{PH}$-domain amino acid sequences from P. citricarpa, P. capitalensis, and other Dothideomycetes also showed well-supported clades for Pleosporales, Botryosphaeriales, and Capnodiales (Fig. 3). However, while the two PH-domain proteins of $P$. citricarpa clustered most closely with the $\mathrm{PH}$-domain protein from $P$. capitalensis, the separate branching of the MAT1-1 copy of the $P$. citricarpa $\mathrm{PH}-$ domain protein reflected its significant divergence (Fig. 3).

Mating type screen of the $P$. citricarpa population in Florida. In preliminary trials with the Australian BRIP 27888 and the Floridian Gc12 isolates, the newly designed MAT1-1-specific primer pair (Gcmat1-1) amplified a 630-bp band from isolate BRIP 27888 only and the MAT1-2-specific primer pair (Gcmat1-2) produced a 500-bp amplicon from Gc12 only (Fig. 4). These amplicons were easily differentiated by agarose gel electrophoresis, and DNA sequencing of the amplicons verified their specific MAT locus identities (data not shown). Neither primer pair generated an amplicon when $P$. capitalensis gDNA was used as template, thus demonstrating the species-specificity of the primers (Fig. 4A). Among the entire collection $(n=113)$ of Floridian P. citricarpa isolates, a single 500-bp amplicon was generated from the gDNA for all isolates with the MAT1-2-specific primers (Table 4; Fig. 4B). No amplicon was produced with the MAT1-1-specific primers. Of the $26 \mathrm{gDNA}$ samples of $P$. citricarpa from Australia, a nearly equal portion of amplicons from the MAT1-1-specific and the MAT1-2-specific primer pairs were generated. These were of the expected 630- and 500-bp size, respectively (Table 4; Fig. 4B). A $\chi^{2}$ analysis showed that the ratio of MAT1-1 and MAT1-2 MAT amplicons in the Australian population was not significantly different from $1: 1\left(\chi^{2}=0.0435, P=0.8348\right)$. In addition, three gDNA samples from Australian isolates amplified both a 500- and

\section{P. citricarpa}

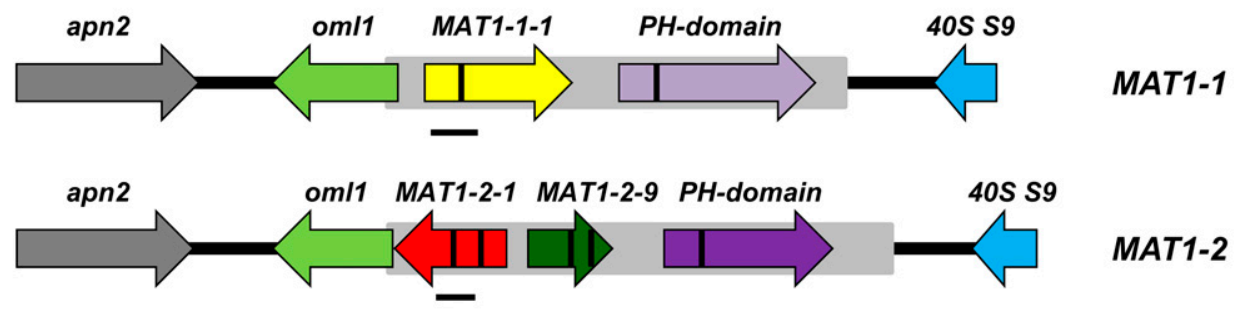

P. capitalensis

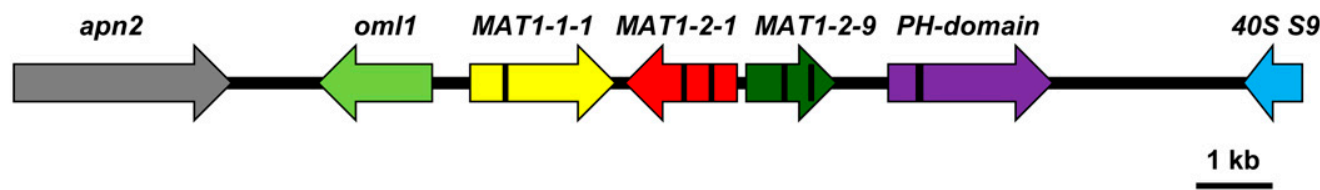

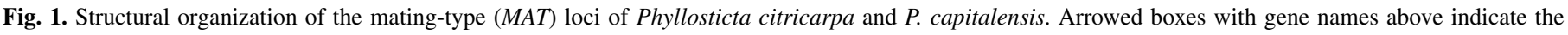

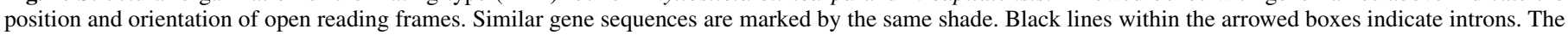

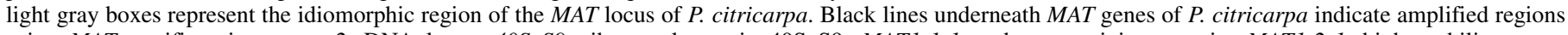

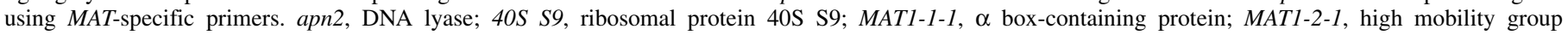

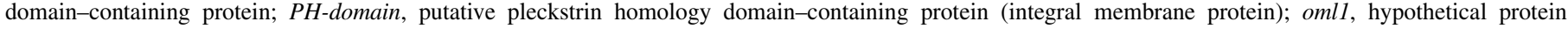
(overlapping MAT locus 1); MAT1-2-9, hypothetical protein. The figure is to scale. 
a 630-bp product, indicative of potential heterokaryosis among field isolates (Table 4).

Screening and amplification of SSR markers. Based on the outputs of BachPrimer3 for the two P. citricarpa genomes (isolates Gc12 and CGMCC3.14348), 13 primer pairs identical in both genomes but predicted to amplify polymorphic SSR loci were selected for touchdown PCR amplification (Table 2). Each primer pair, except marker 28, consistently amplified a single fragment from Floridian and Australian isolates. All markers were monomorphic across all isolates from the Floridian population tested (Table 2), except two isolates in which the primers failed to amplify.
Seven of the tested markers showed polymorphism for the Australian population (Table 2). The allele number of each marker varied from 2 to 4 , and the Hexp (unbiased genotypic diversity index) values ranged from 0.16 to 0.81 (Table 2).

Diversity and population structure of $\boldsymbol{P}$. citricarpa isolates. All 70 isolates tested from Florida belonged to a single multilocus genotype (MLG); however, the Australian population consisted of 11 unique MLGs resolved from seven SSR markers (Table 5; Supplementary Table S1; Fig. 5). Of the Australian population, four isolates belonged to the same MLG, MLG5, as the Floridian population. No genotype diversity was present in the Floridian
A

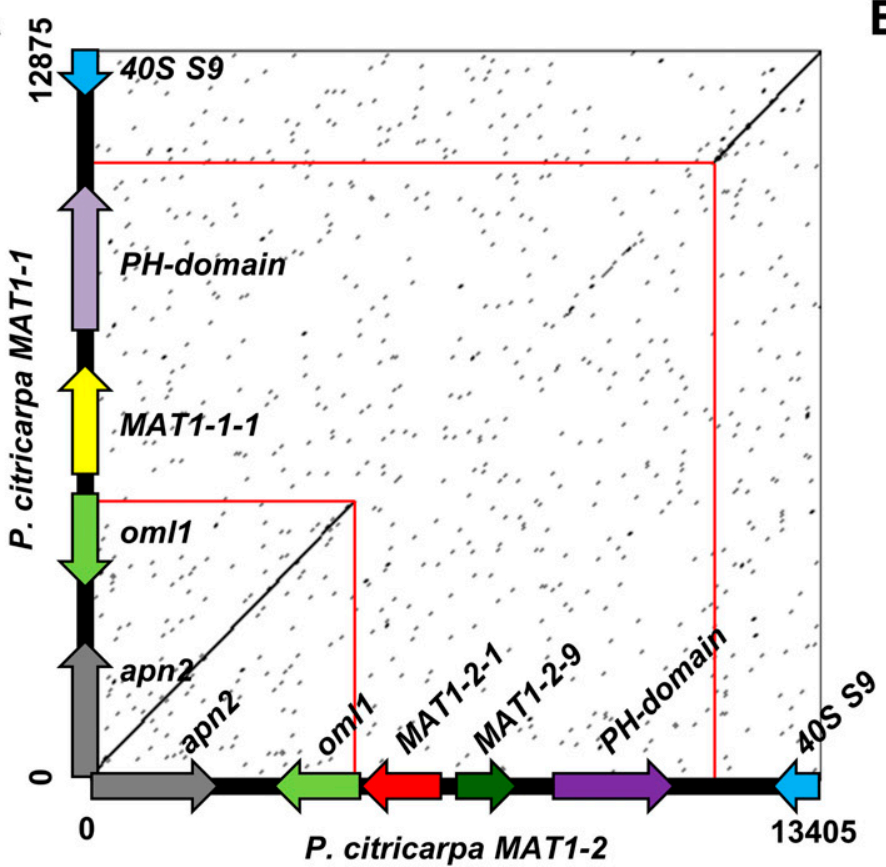

B

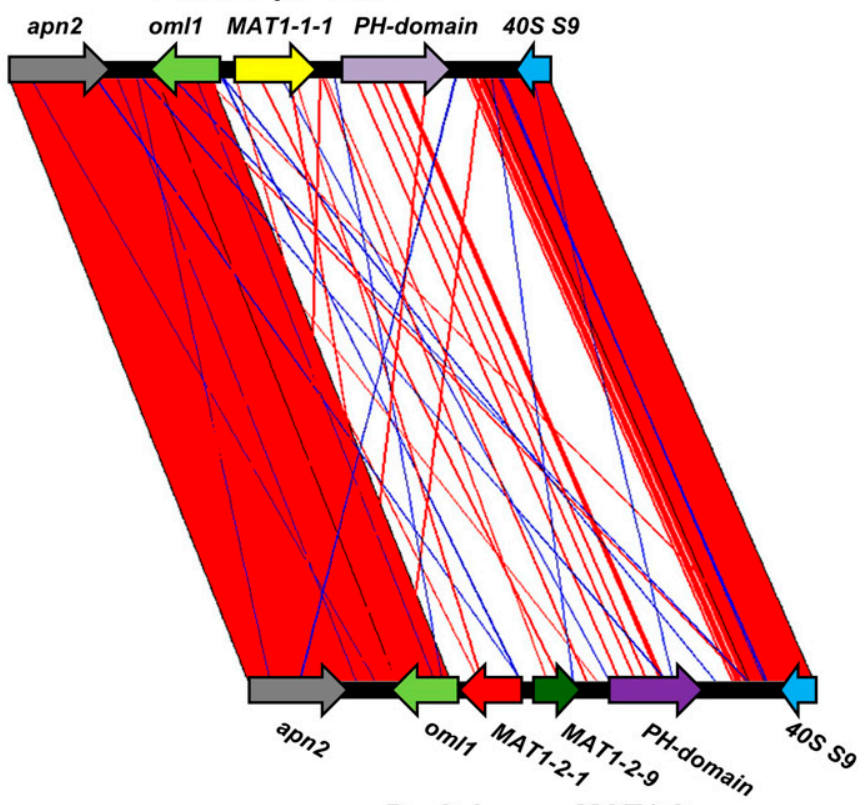

P. citricarpa MAT1-2

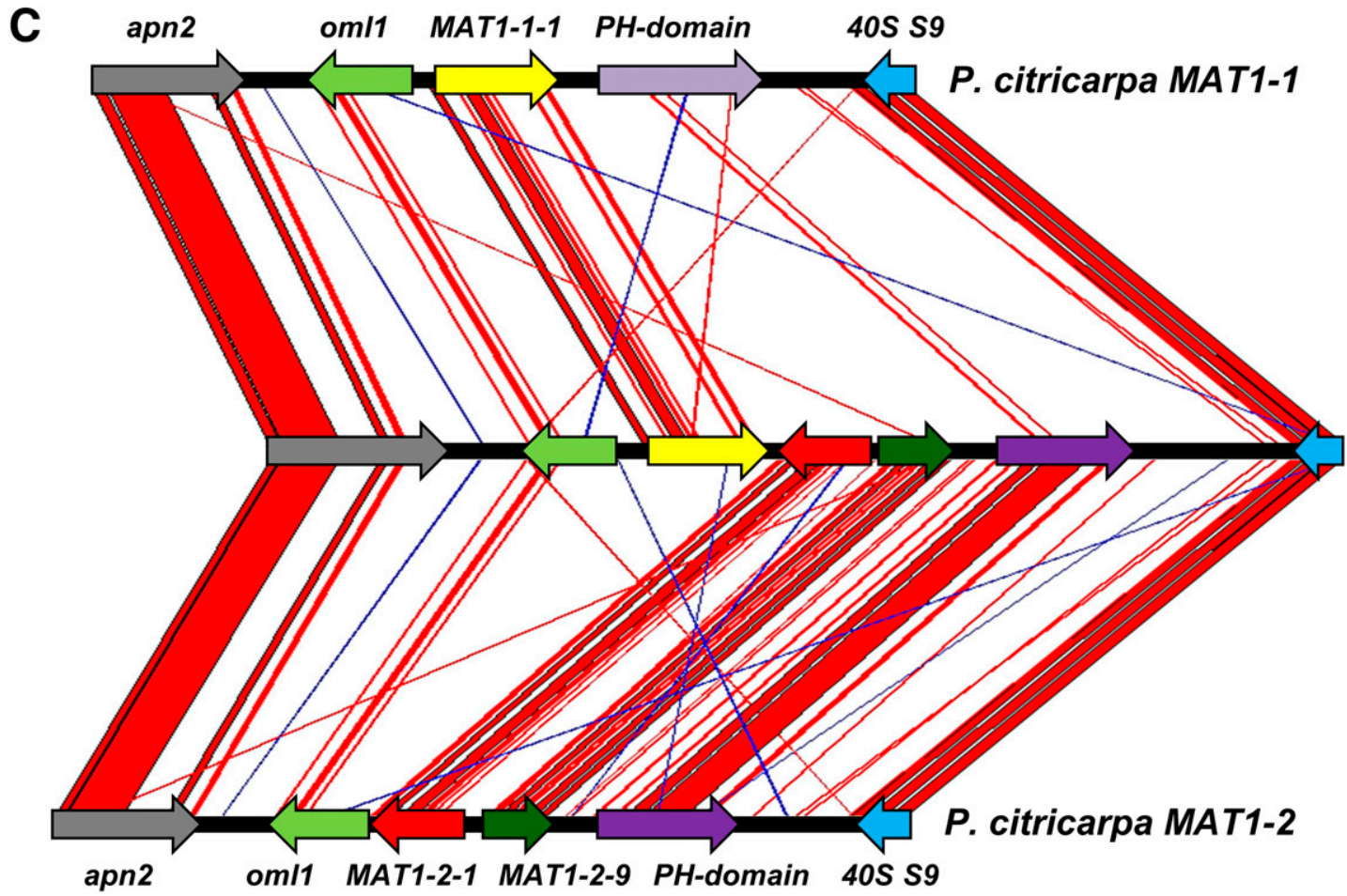

P. capitalensis MAT

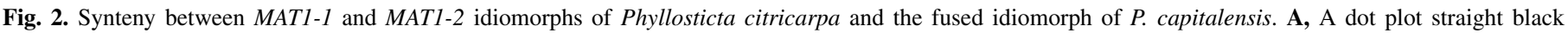

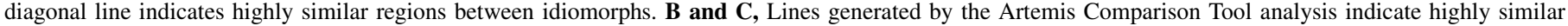
regions in the forward and reverse directions between idiomorphs. 
population $(\mathrm{G}=1)$ and significant genotype diversity was present in the Australian population $(\mathrm{G}=5.88)$ (Table 5). The unbiased genotypic diversity was also greater in the Australian population $(\mathrm{Hexp}=0.87)$ than in the Floridian population $(\mathrm{Hexp}=0)$. The observed $I_{A}$ and $\bar{r}_{d}$ values for the Australian population were 0.17 and 0.03 , respectively, which did not significantly differ from those obtained from randomized data $\left(P=0.131\right.$ for $I_{A}$ and $P=0$ for $\left.\bar{r}_{d}\right)$.

\section{DISCUSSION}

In areas of the world where citrus black spot has become established, pseudothecia are produced in the leaf litter, and ascospores are thought to be responsible for the majority of new fruit infections and spread within the grove (Kiely 1948; Kotzé

TABLE 3. Percent nucleotide and amino acid identity of the mating-type (MAT) loci between Phyllosticta citricarpa and P. capitalensis $^{\mathrm{a}}$

\begin{tabular}{|c|c|c|c|}
\hline \multirow[b]{2}{*}{ P. capitalensis } & \multicolumn{2}{|r|}{ P. citricarpa } & \multirow{2}{*}{$\begin{array}{c}\text { Sequence } \\
\text { identity }(\%)^{\mathrm{b}}\end{array}$} \\
\hline & Idiomorph & Gene & \\
\hline omll & MAT1-1 & oml1 & $55(40)$ \\
\hline & MAT1-2 & oml1 & $57(24)$ \\
\hline MAT1-1-1 & $M A T 1-1$ & MAT1-1-1 & 68 (59) \\
\hline$M A T 1-2-1$ & MAT1-2 & MAT1-2-1 & $70(65)$ \\
\hline$M A T 1-2-9$ & MAT1-2 & MAT1-2-9 & $69(48)$ \\
\hline $\begin{array}{l}\text { PH domain- } \\
\text { encoding gene }\end{array}$ & $\begin{array}{l}\text { MAT1-1 } \\
\text { MAT1-2 }\end{array}$ & $\begin{array}{l}\text { PH domain-encoding gene } \\
\text { PH domain-encoding gene }\end{array}$ & $\begin{array}{l}54(41) \\
72(67)\end{array}$ \\
\hline
\end{tabular}

a Nucleotide and amino acid sequences were predicted using the AUGUSTUS web interface with Botrytis cinerea as the model organism.

b Sequence identity was analyzed using the Needleman-Wunsch global alignment algorithum available on the website of the National Center for Biotechnology Information. Nucleotide identities are presented with amino acid identities in parentheses.
1981; McOnie 1964; Reis et al. 2006; Spósito et al. 2008). Given this epidemiology, regulation of sexual reproduction in $P$. citricarpa and critical factors involved for this process are of both practical and fundamental value. Deciphering the makeup and structure of the MAT locus as well as the distribution of idiomorphs within the populations, as reported here, is an important step in gaining this understanding. We first discovered that the Floridian isolate of $P$. citricarpa (Gc12), characterized in this study, only contained the MAT1-2 idiomorph. The presence of only one idiomorph is consistent with the lack of self-fertility in culture (Baayen et al. 2002; Baldassari et al. 2008) and is supported by multiple other lines of evidence. First, from the draft genome sequence established here, the assembled 28.9-kb contig containing the MAT1-2-1 coding sequence contained an additional $13.1 \mathrm{~kb}$ of upstream and $14.3 \mathrm{~kb}$ of downstream sequence, with no sequence homology to known MAT1-1 genes. Further, given the significant sequencing coverage (approximately $75 \times$ ), if MAT1-1-1 genes existed in close proximity with the MAT1-2-1 gene, as found in homothallic P. capitalensis Gm33 in this study, it would be expected to be found within this region. Third, MAT1-1-1 sequences, but no evidence of MAT1-2-1 sequences, were identified in the P. citricarpa CGMCC 3.14348 genome. Fourth, mating type screening using $M A T$-specific primers clearly showed that $P$. citricarpa isolates in the Floridian and Australian populations were either MAT1-1 or MAT1-2, with the exception of a few presumed heterokaryotic isolates identified in the Australian population. It is possible that these isolates were impure, as DNA from single-spored isolates was not available at the time of the study. Thus, the evidence presented here indicates that $P$. citricarpa is heterothallic.

The boundaries of fungal MAT loci can generally be determined based on the conserved flanking genes and genetic content. However, these criteria were not completely applicable to $P$. citricarpa. Studies have reported conserved genes that commonly flank the MAT loci of ascomycetes and zygomycetes (Debuchy and Turgeon 2006;

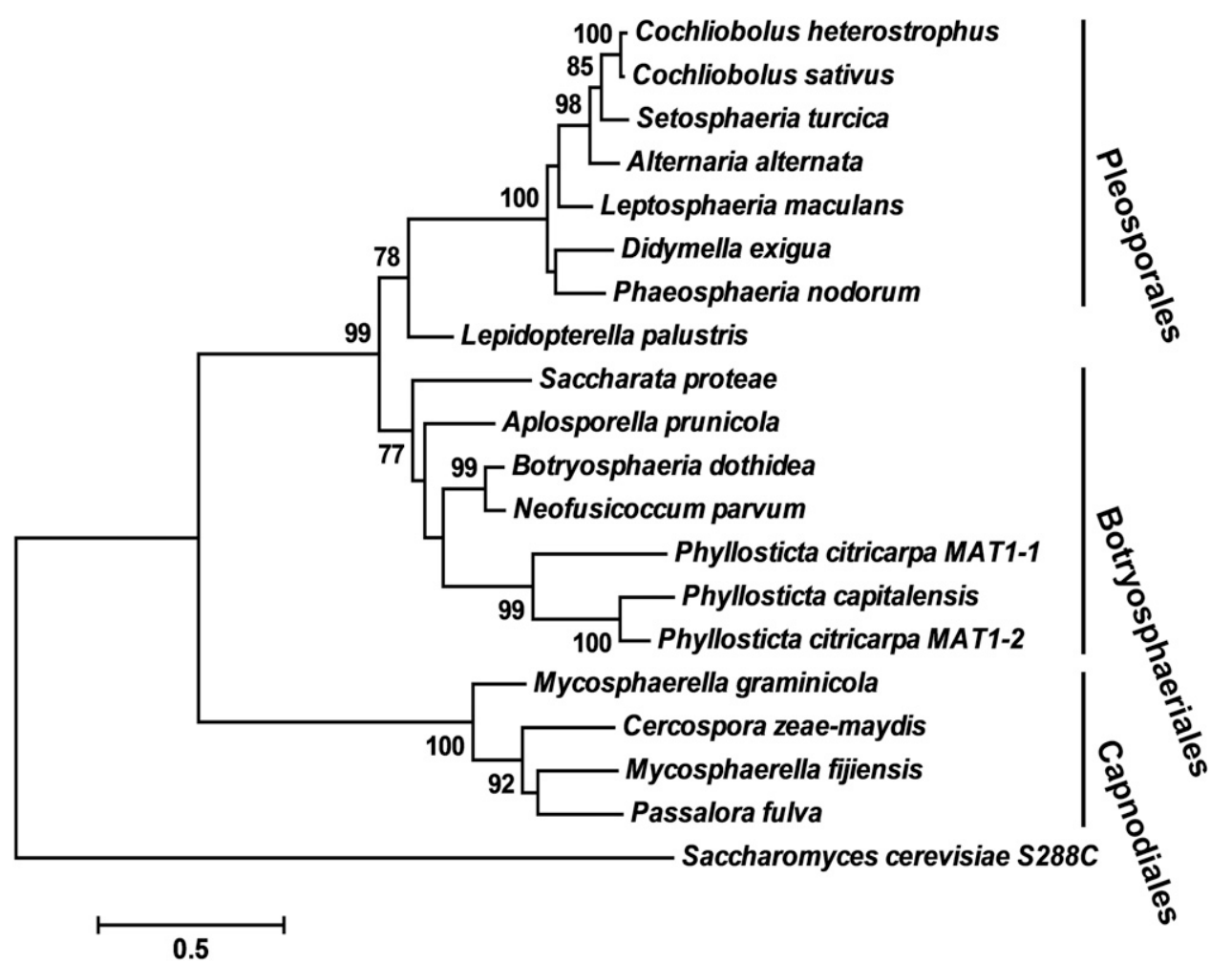

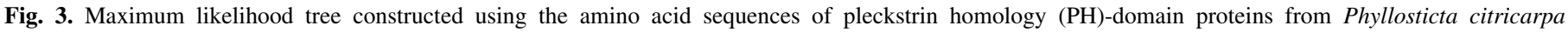

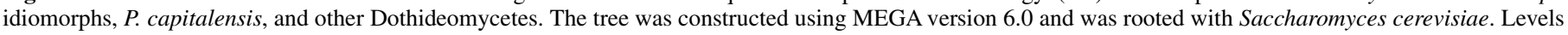

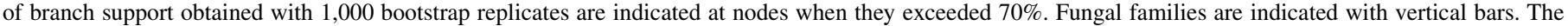
scale bar represents 0.5 substitutions per site. 
Gryganskyi et al. 2010; Lee et al. 2010). Of them, apn2 and sla2 are most commonly found adjacent to MAT loci in ascomycetes (Debuchy and Turgeon 2006; Lee et al. 2010). But in Dothideomycetes, only apn2 is commonly found in the flanking region of the MAT locus (Debuchy and Turgeon 2006) and other genes, such as the $40 S S 9$ gene that we observed in P. citricarpa and the gapl gene (GTPase activating protein) in Leptosphaeria maculans (Cozijnsen and Howlett 2003), rather than the sla2 gene, commonly define the other flank. This limited conservation of the downstream flank explains our failure to amplify the MAT locus in initial cloning attempts. Syntenic analysis between the MAT idiomorphs of $P$. citricarpa revealed that the conserved flanking sequences of the MAT locus begin upstream in the $5^{\prime}$ end of the omll gene rather than in an intergenic region. This structure is rare but found in the MAT loci of Magnaporthe grisea, Cordyceps takaomontana, Aspergillus fumigatus, and Pyrenopeziza brassicae, in which one

A Gcmat1-1 Gcmat1-2

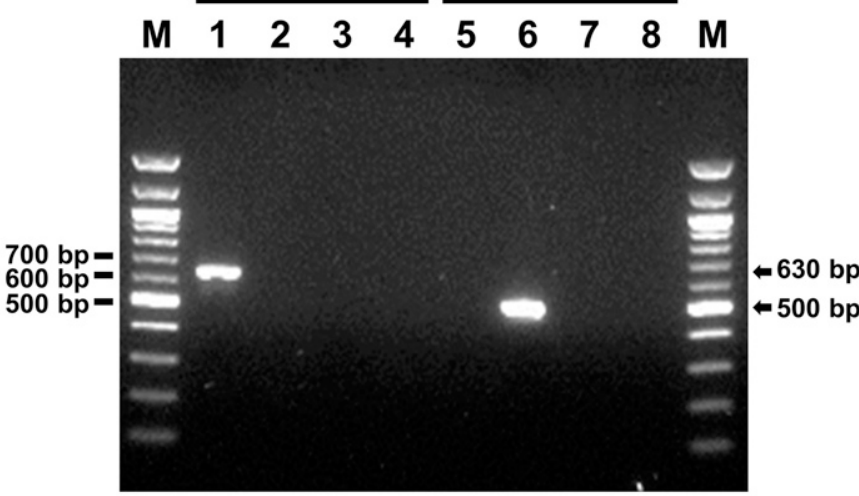

B

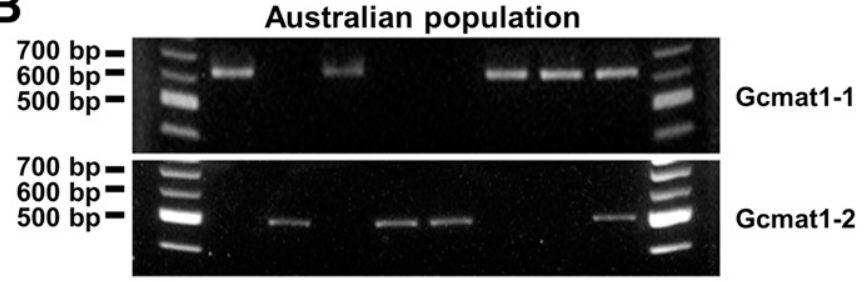

Floridian population

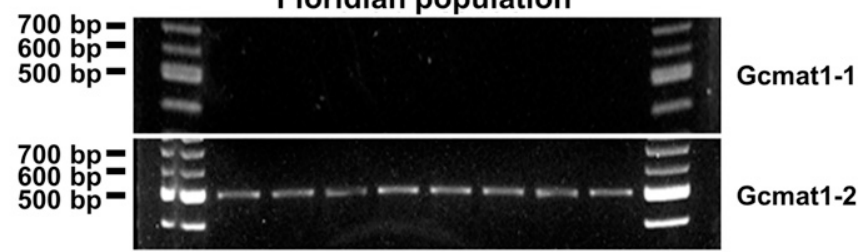

Fig. 4. Specificity verification of the mating-type (MAT) primers for Phyllosticta citricarpa by conventional polymerase chain reaction (PCR). A, M, 100-bp DNA marker; lanes 1 and 5, P. citricarpa BRIP 27888 from Australia served as a positive control of the MATI-1 idiomorph; lanes 2 and 6, P. citricarpa Gc12 served as a positive control of the MAT1-2 idiomorph; lanes 3 and 7, P. capitalensis Gm33 served as a negative control; lanes 4 and 8 , nuclease-free water served as a nontemplate control. B, Representative samples from Australia (BRIP 54234-54241) and Florida (GCCN1s-8s).

TABLE 4. Evaluation of mating-type (MAT) idiomorphs among Phyllosticta citricarpa isolates collected in Florida from 2010 to 2014 and genomic DNA samples from Queensland, Australia, using MAT-specific primers designed in the study

\begin{tabular}{lcccc}
\hline & \multirow{2}{*}{$\begin{array}{c}\text { Total number } \\
\text { of isolates }\end{array}$} & \multicolumn{3}{c}{ Number of isolates } \\
\cline { 3 - 5 } Population & 113 & 0 & 113 & 0 \\
\hline Florida, U.S.A. & 26 & 12 & 11 & 3 \\
Queensland, Australia & 26 & MAT1-2 & Heterokaryon \\
\hline
\end{tabular}

of their MAT genes or lineage-specific genes extends from the idiomorphic region into the flanking region (Debuchy and Turgeon 2006; Paoletti et al. 2005; Singh and Ashby 1998; Yokoyama et al. 2003). The encoded OML1 protein of $P$. citricarpa shared homology with MAT1-1-4 of $D$. pinea, which is located in its MAT1-1 idiomorph (Bihon et al. 2014), implying a possibility that the incorporation of the omll gene into the MAT locus of $P$. citricarpa is ongoing. The expansion of MAT loci has been observed in Coccidioides species, Mycosphaerella species, and, the most striking case, Cryptococcus neoformans, in which extensive rearrangements of genes were found between the two idiomorphs (over $100 \mathrm{~kb}$ ) (Arzanlou et al. 2010; Lengeler et al. 2002; Mandel et al. 2007). These findings are consistent with the evolution of $M A T$ loci toward sex chromosomes (Lengeler et al. 2002).

In contrast to $P$. citricarpa, the MAT locus of $P$. capitalensis harbors both MAT1-1-1 and MAT1-2-1 genes as well as the MAT1-2-9 ortholog and a single PH domain-encoding gene. This organization was also present in the MAT locus of another presumably homothallic Botryosphaeriales fungus, $B$. dothidea. The structurally homothallic MAT locus in P. capitalensis is consistent with the previous observation that $P$. capitalensis can produce pseudothecia and ascospores in single spore-derived cultures (Baayen et al. 2002; Baldassari et al. 2008). The presence of a single PH domain-encoding gene in the homothallic locus as well as in each of the heterothallic idiomorphs presents an additional instance in which the distinction between conserved flanking sequence and idiomorphic sequences becomes blurred. Surprisingly, in the $P$. citricarpa idiomorphs the two PH-domain genes shared only $56 \%$ nucleotide identity, whereas the $P$. citricarpa MAT1-2 PH-domain gene shared $72 \%$ nucleotide identity with the $P$. capitalensis $\mathrm{PH}$-domain gene. Based on this intraspecies sequence divergence, the $\mathrm{PH}$-domain genes are considered part of the $P$. citricarpa idiomorph. Our analysis of other available genome sequences (Supplementary Table S3) determined that, with the exception of $P$. citricarpa, the PH-domain gene is often found adjacent to the MAT idiomorphs in Dothideomycetes rather than a member of the idiomorph. This evidence combined with our findings of the divergent $5^{\prime}$ sequences of omll indicates that $P$. citricarpa has expanded its idiomorphic regions by the incorporation of flanking sequences, including the $\mathrm{PH}$-domain gene that is frequently found adjacent to MAT idiomorphs.

Analysis of the MAT locus also gave us our first indication that genetic diversity in the Floridian population of $P$. citricarpa was limited. Isolate screening revealed that only the MAT1-2 idiomorph was present in the $P$. citricarpa isolates collected in Florida. This result implies that $P$. citricarpa only reproduces asexually in Florida and there is a possibility of the existence of a single clonal population. Previously, Zavala et al. (2014) investigated the genetic diversity of Phyllosticta spp. collected in Florida, using multilocus

TABLE 5. Genotypic diversity of the Floridian and Australian populations of Phyllosticta citricarpa

\begin{tabular}{lccrcccc}
\hline Population & $\mathrm{N}^{\mathrm{a}}$ & $\mathrm{MLG}^{\mathrm{b}}$ & $\mathrm{eMLG}^{\mathrm{N}} \pm \mathrm{SE}^{\mathrm{b}}$ & $\mathrm{H}^{\mathrm{c}}$ & $\mathrm{G}^{\mathrm{c}}$ & $\mathrm{Hexp}^{\mathrm{d}}$ & $\mathrm{E}^{\mathrm{e}}$ \\
\hline Australia & 24 & 11 & $11.0 \pm 0.0$ & 2.04 & 5.88 & 0.87 & 0.73 \\
Florida & 70 & 1 & $1.0 \pm 0.0$ & 0.00 & 1.00 & 0.00 & $\mathrm{NaN}^{\mathrm{f}}$ \\
\hline
\end{tabular}

a $\mathrm{N}$, number of individuals.

b $\mathrm{MLG}=$ number of multilocus genotypes observed; $\mathrm{eMLG} \pm \mathrm{SE}=$ number of expected MLG at the smallest sample size $\geq 10$ based on rarefaction \pm standard error. Under random mating, eMLG would be equal to MLG.

c $\mathrm{H}=$ Shannon-Wiener index of MLG diversity, $\mathrm{G}=$ Stoddart and Taylor's index of MLG diversity; the greater H or G, the more diverse the population.

d Hexp = Nei's unbiased genotypic diversity, the probability of two randomly chosen genotypes being different, ranging from zero to one; the greater the value, the greater the diversity.

e E.5 = evenness, the distribution of genotype abundances, ranging from zero, where a single genotype is dominant within a population, to one, where genotypes are equally abundant within a population.

f $\mathrm{NaN}=$ not a number. 
phylogenetic analysis, with sequences from ITS, ACT, TEF1, and GPDH loci. Their results revealed no sequence polymorphisms within loci among P. citricarpa isolates from Florida, Brazil, Australia, and Africa. In an independent study with these same loci, $P$. citricarpa isolates from Australia clustered in the same clade and exhibited limited phylogenetic diversity (Glienke et al. 2011). These results suggested that markers based on other than highly conserved genes were needed to resolve phylogenetic relationships and population structure within the species. Our test of this hypothesis with newly developed SSR markers established that MLG5 is the only genotype in the Floridian population of $P$. citricarpa. In contrast, $11 \mathrm{MLG}$ were revealed among the 24 Australian isolates, with high genetic diversity relative to the lack of diversity in Florida.

The clonality of the P. citricarpa population in Florida is likely derived from a founder effect (Provine 2004) similar to what has
A

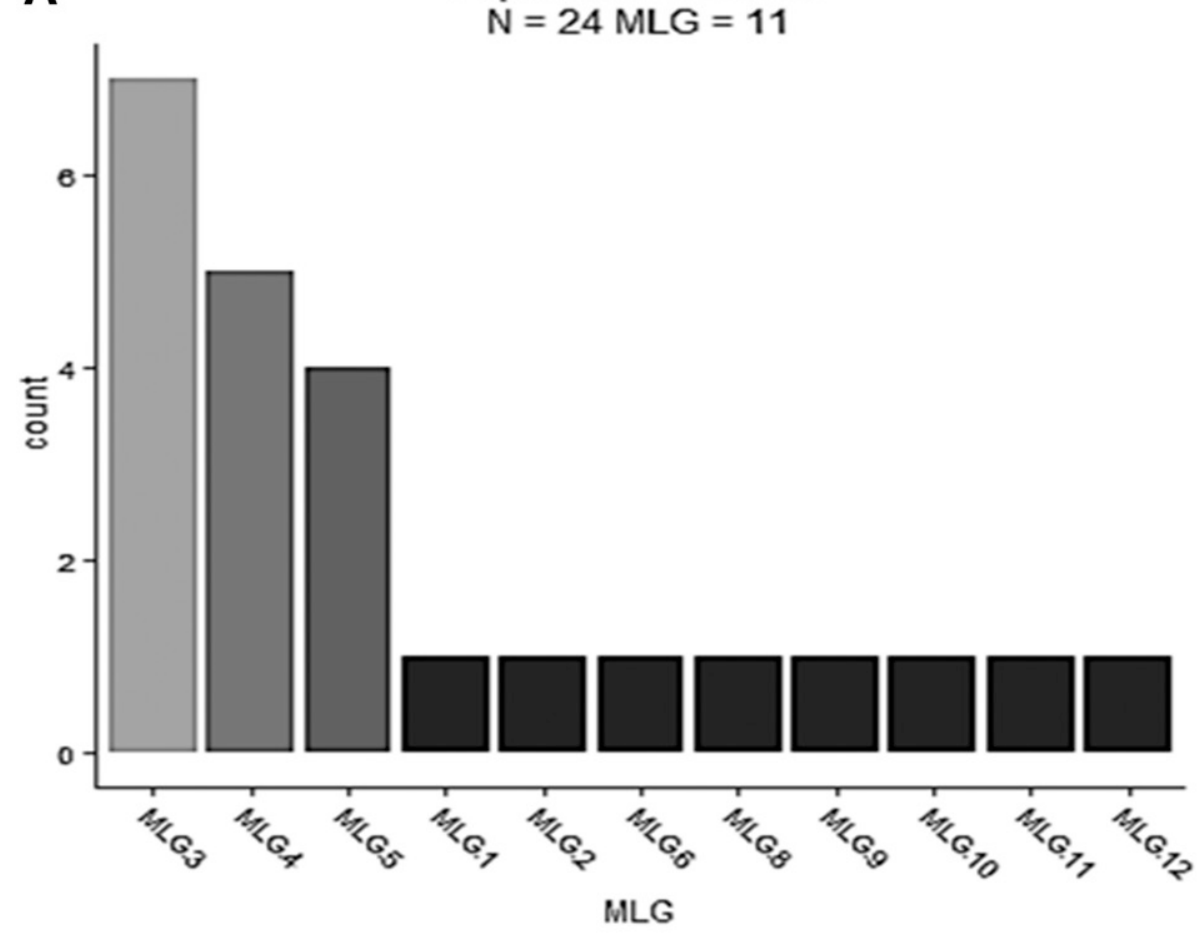

B

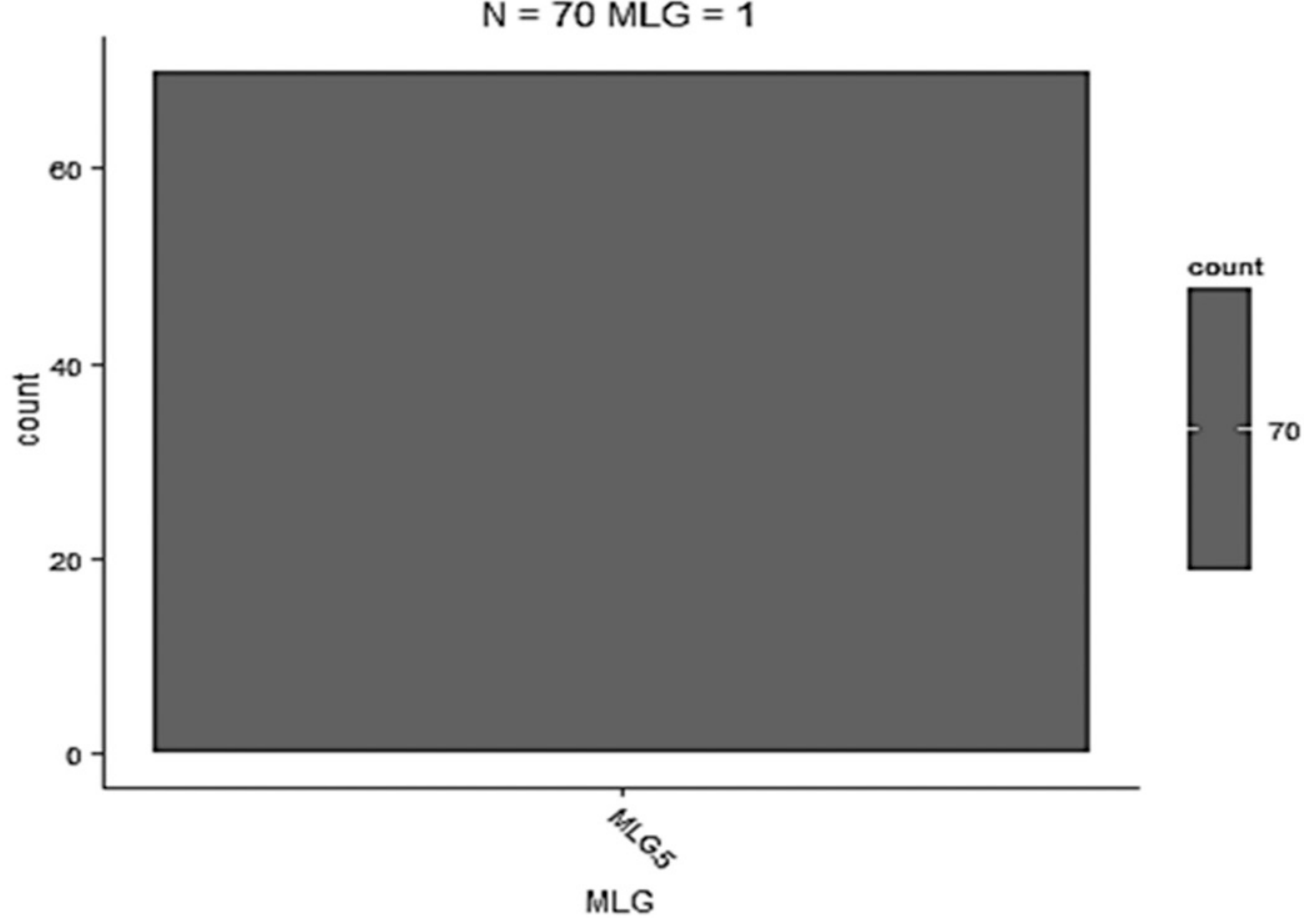

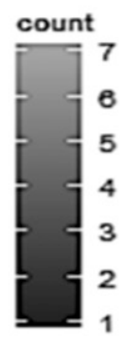

Population: Florida

$\mathrm{N}=70 \mathrm{MLG}=1$

Fig. 5. Distribution of multilocus genotypes (MLG) of A, Australian and B, Floridian populations of Phyllosticta citricarpa. This result shows that 11 MLG were found in Australia but only one MLG was found in the Floridian population. 
been observed in Cryptococcus gattii (Carriconde et al. 2011) and the global population of Phytophthora infestans before 1976 (Fry et al. 1993). Expanded genotypic diversity in the Australian population (11 MLGs among 24 isolates) may be attributed to the length of time P. citricarpa has been in Australia (Benson 1895), the possibility of multiple and larger past introductions and regular sexual recombination due to the presence of both mating types. Although four Australian isolates shared their MLG with the Floridian population, this is not evidence for the origin of the Floridian population in Australia. A broader, global survey of populations with an expanded set of genotypic markers will be required to generate hypotheses on the center of $P$. citricarpa diversity and the source of the Floridian population. Screening of new $P$. citricarpa isolates is ongoing to monitor for new introductions that could establish the opposite mating type and, potentially, the sexual cycle in Florida.

In other parts of the world, the disease cycle of citrus black spot is thought to depend on ascospores to initiate infections and spread the disease through and between groves (Kotzé 1981; McOnie 1964; Reis et al. 2006; Spósito et al. 2008). However, accounts from early stages of disease establishment in Rhodesia (Zimbabwe) determined that most fruit infections occurred from conidial inoculum and only small numbers of ascospores were found in leaf litter (Whiteside 1967). Because this study was conducted prior to the advent of molecular identification, it is uncertain whether the detected ascospores were from $P$. citricarpa or $P$. capitalensis. Even in the presence of ascospores, conidia produced under favorable environmental conditions, such as frequent summer rains, can become dominant in the spread of the disease within tree canopies, as shown in Brazil (Spósito et al. 2011). With the presence of only a single mating type in Florida, ascosporic inoculum is unlikely to exist. This places citrus black spot epidemiology in Florida in a unique situation in which inoculum production and spread would solely depend on conidia produced on dead twigs, fruit lesions, leaves, and in leaf litter. These forms of conidial inoculum have been demonstrated to be important in Brazil (Spósito et al. 2011), where climate and production patterns are similar to Florida. It will be interesting to determine the presence and pattern of mating type idiomorphs and the population structure among Brazilian isolates of $P$. citricarpa to better understand the relative contributions of the sexual and asexual cycles to disease development.

The findings of this study should be applicable to reducing the severity and the spread of citrus black spot. While the majority of citrus produced in Florida is grown for juice processing, certain citrus types, such as grapefruit and specialty fresh fruit, are destined for the fresh fruit market and export (Florida Agricultural Statistics Service 2015). As such, it is important to continue to reduce disease spread to facilitate market access. Current measures to restrict the movement of infected plant debris including the removal of debris from and disinfection of grove equipment are still highly advisable, as conidia can be produced in large numbers on infected twigs and leaf litter. For disease management, further emphasis should be placed on the removal of dead wood from trees. Disease management in the more susceptible cultivars, such as Valencia, is more complicated because the mature fruit overlap with young fruit, leading to greater inoculum potential for the younger fruit. Fungicide applications during this period (May to September) should be considered important for disease management in Florida.

In conclusion, this study identified the MAT loci of $P$. citricarpa and $P$. capitalensis and determined the presence of only the MAT1-2 idiomorph in a clonal Floridian population of $P$. citricarpa. As a consequence, the presumed ascospore production of $P$. citricarpa in leaf litter in Florida is unlikely. This shows that the $P$. citricarpa does have a heterothallic mating type structure, as hypothesized, but the Floridian population is not randomly mating, as only asexual reproduction can currently occur. Therefore, the importance of $P$. citricarpa conidia as the sole inoculum source should not be underestimated. Future research should focus on the impact of the asexual cycle on the epidemiology of citrus black spot in Florida and the conditions that may reduce conidial inoculum production.

\section{ACKNOWLEDGMENTS}

We thank U. Benny, K. F. Rodrigues, and D. A. Moraga Amador for the technical assistance. We also thank A. K. Miles for the DNA samples from Australia and J. Wang and M. Ascunce for advice on population genetics. This project was funded by Citrus Research and Development Foundation (grant numbers 411 and 715 ) and the Florida Citrus Initiative.

\section{LITERATURE CITED}

Arie, T., Christiansen, S. K., Yoder, O. C., and Turgeon, B. G. 1997. Efficient cloning of ascomycete mating type genes by PCR amplification of the conserved MAT HMG box. Fungal Genet. Biol. 21:118-130.

Arie, T., Kaneko, I., Yoshida, T., Noguchi, M., Nomura, Y., and Yamaguchi, I. 2000. Mating-type genes from asexual phytopathogenic ascomycetes Fusarium oxysporum and Alternaria alternata. Mol. Plant-Microbe Interact. 13:1330-1339.

Arzanlou, M., Crous, P. W., and Zwiers, L.-H. 2010. Evolutionary dynamics of mating-type loci of Mycosphaerella spp. occurring on banana. Eukaryot. Cell 9:164-172.

Baayen, R. P., Bonants, P. J. M., Verkley, G., Carroll, G. C., van der Aa, H. A., de Weerdt, M., van Brouwershaven, I. R., Schutte, G. C., Maccheroni, W., Jr., Glienke de Blanco, C., and Azevedo, J. L. 2002. Nonpathogenic isolates of the citrus black spot fungus, Guignardia citricarpa, identified as a cosmopolitan endophyte of woody plants, G. mangiferae (Phyllosticta capitalensis). Phytopathology 92:464-477.

Baldassari, R. B., Wickert, E., and de Goes, A. 2008. Pathogenicity, colony morphology and diversity of isolates of Guignardia citricarpa and G. mangiferae isolated from Citrus spp. Eur. J. Plant Pathol. 120:103-110.

Bankevich, A., Nurk, S., Antipov, D., Gurevich, A. A., Dvorkin, M., Kulikov, A. S., Lesin, V. M., Nikolenko, S. I., Pham, S., Prjibelski, A. D., Pyshkin, A. V., Sirotkin, A. V., Vyahhi, N., Tesler, G., Alekseyev, M. A., and Pevzner, P. A. 2012. SPAdes: A new genome assembly algorithm and its applications to single-cell sequencing. J. Comput. Biol. 19:455-477.

Bennett, R. S., Yun, S. H., Lee, T. Y., Turgeon, B. G., Cunfer, B., Arseniuk, E., and Bergstrom, G. C. 1999. Mating type-specific PCR primers for Stagonospora nodorum field studies. Pages 90-92 in: Septoria and Stagonospora Diseases of Cereals: A Compilation of Global Research. M. van Ginkel, M. A. McNab, and J. Krupinsky, eds. CIMMYT, El Batan, Mexico.

Benson, A. H. 1895. Black spot of the orange. Agric. Gaz. N. S. W. 6:249-251.

Bihon, W., Wingfield, M. J., Slippers, B., Duong, T. A., and Wingfield, B. D. 2014. MAT gene idiomorphs suggest a heterothallic sexual cycle in a predominantly asexual and important pine pathogen. Fungal Genet. Biol. 62: 55-61.

Butler, G., Rasmussen, M. D., Lin, M. F., Santos, M. A., Sakthikumar, S., Munro, C. A., Rheinbay, E., Grabherr, M., Forche, A., Reedy, J. L., Agrafioti, I., Arnaud, M. B., Bates, S., Brown, A. J., Brunke, S., Costanzo, M. C., Fitzpatrick, D. A., de Groot, P. W., Harris, D., Hoyer, L. L., Hube, B., Klis, F. M., Kodira, C., Lennard, N., Logue, M. E., Martin, R., Neiman, A. M., Nikolaou, E., Quail, M. A., Quinn, J., Santos, M. C., Schmitzberger, F. F., Sherlock, G., Shah, P., Silverstein, K. A., Skrzypek, M. S., Soll, D., Staggs, R., Stansfield, I., Stumpf, M. P., Sudbery, P. E., Srikantha, T., Zeng, Q., Berman, J., Berriman, M., Heitman, J., Gow, N. A., Lorenz, M. C., Birren, B. W., Kellis, M., and Cuomo, C. A. 2009. Evolution of pathogenicity and sexual reproduction in eight Candida genomes. Nature 459: 657-662.

Carriconde, F., Gilgado, F., Arthur, I., Ellis, D., Malik, R., van de Wiele, N., Robert, V., Currie, B. J., and Meyer, W. 2011. Clonality and $\alpha$-a recombination in the Australian Cryptococcus gattii VGII population-An emerging outbreak in Australia. PLoS One 6:e16936.

Carver, T. J., Rutherford, K. M., Berriman, M., Rajandream, M.-A. A., Barrell, B. G., and Parkhill, J. 2005. ACT: The Artemis comparison tool. Bioinformatics 21:3422-3423.

Cozijnsen, A. J., and Howlett, B. J. 2003. Characterisation of the mating-type locus of the plant pathogenic ascomycete Leptosphaeria maculans. Curr. Genet. 43:351-357.

de Goes, A., Baldassari, R. B., Feichtenberger, E., Aguilar-Vildoso, C. I., and Spósito, M. B. 2000. Cracked spot, a new symptom of citrus black spot (Guignardia citricarpa) in Brazil. Page 145 in: 9th International Citrus Congress of the International Society of Citriculture. Orlando, Florida.

Debuchy, R., and Turgeon, B. G. 2006. Mating-type structure, evolution, and function in euascomycetes. Pages 293-323 in: The Mycota I: Growth, Differentiation, and Sexuality. Kües, U., and Fischer, R., eds. SpringerVerlag, Berlin, Heidelberg. 
European Food Safety Authority (EFSA). 2014. Scientific Opinion on the risk of Phyllosticta citricarpa (Guignardia citricarpa) for the EU territory with identification and evaluation of risk reduction options. EFSA J. 12:3557.

Florida Agricultural Statistics Service. 2015. Page 117 in: Florida Citrus Statistics, 2013-2014. Florida Department of Agriculture and Consumer Services, Tallahassee, FL.

Fry, W. E., Goodwin, S. B., Dyer, A. T., Matuszak, J. M., Drenth, A., Tooley, P. W., Sujkowski, L. S., Koh, Y. J., Cohen, B. A., Spielman, L. J., Deahl, K. L., Inglis, D. A., and Sandlan, K. P. 1993. Historical and recent migrations of Phytophthora infestans: Chronology, pathways, and implications. Plant Dis. 77:653-661.

Glienke, C., Pereira, O. L., Stringari, D., Fabris, J., Kava-Cordeiro, V., Galli-Terasawa, L., Cunnington, J., Shivas, R. G., Groenewald, J. Z., and Crous, P. W. 2011. Endophytic and pathogenic Phyllosticta species, with reference to those associated with Citrus black spot. Persoonia 26:47-56.

Griebel, T., Brinkmeyer, M., and Böcker, S. 2008. EPoS: A modular software framework for phylogenetic analysis. Bioinformatics 24:2399-2400.

Gryganskyi, A. P., Lee, S. C., Litvintseva, A. P., Smith, M. E., Bonito, G., Porter, T. M., Anishchenko, I. M., Heitman, J., and Vilgalys, R. 2010. Structure, function, and phylogeny of the mating locus in the Rhizopus oryzae complex. PLoS One 5:e15273.

Hincapie, M., Wang, N.-Y., Peres, N. A., and Dewdney, M. M. 2014. Baseline sensitivity of Guignardia citricarpa isolates from Florida to azoxystrobin and pyraclostrobin. Plant Dis. 98:780-789.

Hu, J., Johnson, E. G., Wang, N.-Y., Davoglio, T., and Dewdney, M. M. 2014. qPCR quantification of pathogenic Guignardia citricarpa and nonpathogenic G. mangiferae in citrus. Plant Dis. 98:112-120.

Kamvar, Z. N., Tabima, J. F., and Grünwald, N. J. 2014. Poppr: An R package for genetic analysis of populations with clonal, partially clonal, and/or sexual reproduction. PeerJ 2:e281.

Kiely, T. B. 1948. Preliminary studies of Guignardia citricarpa n. sp.: The ascigerous state of Phoma citricarpa McAlp. and its relation to black spot of citrus. Proc. Linn. Soc. N. S. W. 73:249-292.

Kiely, T. B. 1949. Black spot of citrus in New South Wales coastal orchards. Agric. Gaz. N. S. W. 60:17-20.

Kotzé, J. M. 1981. Epidemiology and control of citrus black spot in South Africa. Plant Dis. 65:945-950.

Lee, S. C., Ni, M., Li, W., Shertz, C., and Heitman, J. 2010. The evolution of sex: A perspective from the fungal kingdom. Microbiol. Mol. Biol. Rev. 74: 298-340.

Lengeler, K. B., Fox, D. S., Fraser, J. A., Allen, A., Forrester, K., Dietrich, F. S., and Heitman, J. 2002. Mating-type locus of Cryptococcus neoformans: A step in the evolution of sex chromosomes. Eukaryot. Cell 1:704-718.

Maizel, J. V., Jr., and Lenk, R. P. 1981. Enhanced graphic matrix analysis of nucleic acid and protein sequences. Proc. Natl. Acad. Sci. USA 78: 7665-7669.

Mandel, M. A., Barker, B. M., Kroken, S., Rounsley, S. D., and Orbach, M. J. 2007. Genomic and population analyses of the mating type loci in Coccidioides species reveal evidence for sexual reproduction and gene acquisition. Eukaryot. Cell 6:1189-1199.

McOnie, K. C. 1964. Source of inoculum of Guignardia citricarpa, the citrus black spot pathogen. Phytopathology 54:64-67.

Miles, A. K., Tan, Y. P., Tan, M. K., Donovan, N. J., Ghalayini, A., and Drenth, A. 2013. Phyllosticta spp. on cultivated Citrus in Australia. Australas. Plant Pathol. 42:461-467.

Moran Lemir, A. H., Stadnik, M. J., Buchenauer, H., and Canton, N. V. 2000. In vitro production of ascospores and pathogenicity of Guignardia citricarpa, causal agent of citrus black spot. Summa Phytopathol. 26:374-376.

Ni, M., Feretzaki, M., Sun, S., Wang, X., and Heitman, J. 2011. Sex in fungi. Annu. Rev. Genet. 45:405-430.

O'Connell, R. J., Thon, M. R., Hacquard, S., Amyotte, S. G., Kleemann, J., Torres, M. F., Damm, U., Buiate, E. A., Epstein, L., Alkan, N., Altmüller, J., Alvarado-Balderrama, L., Bauser, C. A., Becker, C., Birren, B. W., Chen, Z., Choi, J., Crouch, J. A., Duvick, J. P., Farman, M. A., Gan, P., Heiman, D., Henrissat, B., Howard, R. J., Kabbage, M., Koch, C., Kracher, B., Kubo, Y., Law, A. D., Lebrun, M. H., Lee, Y. H., Miyara, I., Moore, N., Neumann, U., Nordström, K., Panaccione, D. G., Panstruga, R., Place, M., Proctor, R. H., Prusky, D., Rech, G., Reinhardt, R., Rollins, J. A., Rounsley, S., Schardl, C. L., Schwartz, D. C., Shenoy, N., Shirasu, K., Sikhakolli, U. R., Stüber, K., Sukno, S. A., Sweigard, J. A., Takano, Y., Takahara, H., Trail, F., Charlotte van der Does, H., Voll, L. M., Will, I., Young, S., Zeng, Q., Zhang, J., Zhou, S., Dickman, M. B., Schulze-Lefert, P., Ver Loren van Themaat, E.,
Ma, L. J., and Vaillancourt, L. J. 2012. Lifestyle transitions in plant pathogenic Colletotrichum fungi deciphered by genome and transcriptome analyses. Nat. Genet. 44:1060-1065.

Paoletti, M., Rydholm, C., Schwier, E. U., Anderson, M. J., Szakacs, G., Lutzoni, F., Debeaupuis, J.-P., Latgé, J.-P., Denning, D. W., and Dyer, P. S. 2005. Evidence for sexuality in the opportunistic fungal pathogen Aspergillus fumigatus. Curr. Biol. 15:1242-1248.

Paul, I., van Jaarsveld, A. S., Korsten, L., and Hattingh, V. 2005. The potential global geographical distribution of Citrus Black Spot caused by Guignardia citricarpa (Kiely): Likelihood of disease establishment in the European Union. Crop Prot. 24:297-308.

Peakall, R., and Smouse, P. E. 2012. GenAlEx 6.5: Genetic analysis in Excel. Population genetic software for teaching and research-an update. Bioinformatics 28:2537-2539.

Peres, N. A., Harakava, R., Carroll, G. C., Adaskaveg, J. E., and Timmer, L. W. 2007. Comparison of molecular procedures for detection and identification of Guignardia citricarpa and G. mangiferae. Plant Dis. 91:525531.

Provine, W. B. 2004. Ernst Mayr: Genetics and speciation. Genetics 167: 1041-1046.

Reis, R. F., Timmer, L. W., and de Goes, A. 2006. Effect of temperature, leaf wetness, and rainfall on the production of Guignardia citricarpa ascospores and on back spot severity on sweet orange. Fitopatol. Bras. 31:29-34.

Schubert, T. S., Dewdney, M. M., Peres, N. A., Palm, M. E., Jeyaprakash, A., Sutton, B. D., Mondal, S. N., Wang, N.-Y., Rascoe, J., and Picton, D. D. 2012. First report of Guignardia citricarpa associated with citrus black spot on sweet orange [Citrus sinensis (L.) Osbeck] in North America. Plant Dis. 96:1225

Schuelke, M. 2000. An economic method for the fluorescent labeling of PCR fragments. Nat. Biotechnol. 18:233-234.

Singh, G., and Ashby, A. M. 1998. Cloning of the mating type loci from Pyrenopeziza brassicae reveals the presence of a novel mating type gene within a discomycete MAT 1-2 locus encoding a putative metallothioneinlike protein. Mol. Microbiol. 30:799-806.

Spósito, M. B., Amorim, L., Bassanezi, R. B., Bergamin Filho, A., and Hau, B. 2008. Spatial pattern of black spot incidence within citrus trees related to disease severity and pathogen dispersal. Plant Pathol. 57:103-108.

Spósito, M. B., Amorim, L., Bassanezi, R. B., Yamamoto, P. T., Felippe, M. R., and Czermainski, A. B. C. 2011. Relative importance of inoculum sources of Guignardia citricarpa on the citrus black spot epidemic in Brazil. Crop Prot. 30:1546-1552.

Spósito, M. B., Amorim, L., Ribeiro, P. J., Jr., Bassanezi, R. B., and Krainski, E. T. 2007. Spatial pattern of trees affected by black spot in citrus groves in Brazil. Plant Dis. 91:36-40.

Tamura, K., Stecher, G., Peterson, D., Filipski, A., and Kumar, S. 2013. MEGA6: Molecular evolutionary genetics analysis version 6.0. Mol. Biol. Evol. 30:2725-2729.

Ter-Hovhannisyan, V., Lomsadze, A., Chernoff, Y. O., and Borodovsky, M. 2008. Gene prediction in novel fungal genomes using an ab initio algorithm with unsupervised training. Genome Res. 18:1979-1990.

Turgeon, B. G., and Yoder, O. C. 2000. Proposed nomenclature for mating type genes of filamentous ascomycetes. Fungal Genet. Biol. 31:1-5.

Vaillancourt, L., Du, M., Wang, J., Rollins, J. A., and Hanau, R. 2000. Genetic analysis of cross fertility between two self-sterile strains of Glomerella graminicola. Mycologia 92:430-435.

Whiteside, J. O. 1967. Sources of inoculum of the black spot fungus Guignardia citricarpa, in infected Rhodesian citrus orchards. Rhod. Zam. Mal. J. Agr. Res. 5:171-177.

Yokoyama, E., Yamagishi, K., and Hara, A. 2003. Structures of the matingtype loci of Cordyceps takaomontana. Appl. Environ. Microbiol. 69:50195022.

Yonow, T., Hattingh, V., and de Villiers, M. 2013. CLIMEX modelling of the potential global distribution of the citrus black spot disease caused by Guignardia citricarpa and the risk posed to Europe. Crop Prot. 44:18-28.

You, F. M., Huo, N., Gu, Y. Q., Luo, M.-C., Ma, Y., Hane, D., Lazo, G. R., Dvorak, J., and Anderson, O. D. 2008. BatchPrimer3: A high throughput web application for PCR and sequencing primer design. BMC Bioinformatics 9:253.

Zavala, M. G. M., Er, H. L., Goss, E. M., Wang, N.-Y., Dewdney, M. M., and van Bruggen, A. H. C. 2014. Genetic variation among Phyllosticta strains isolated from citrus in Florida that are pathogenic or nonpathogenic to citrus. Trop. Plant Pathol. 39:119-128. 